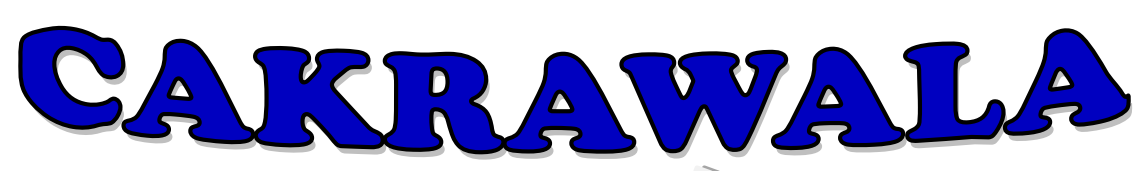

Management Business Journal [C, 2019

\title{
ANALISIS FAKTOR-FAKTOR YANG MEMPENGARUHI STRUKTUR MODAL PADA PERUSAHAAN MANUFAKTUR DI BURSA EFEK INDONESIA PERIODE 2014-2018
}

\author{
Sitti Nur Annisa Rumasukun ${ }^{1}$,Nurwidianto ${ }^{2}$, Agnes Soukotta ${ }^{3}$ \\ Universitas Papua ${ }^{1,2,3}$
}

Correspondence email:n.nurwidianto@unipa.ac.id

\begin{abstract}
ABSTRAK
Penelitian ini bertujuan untuk menganalisis apakah terdapat pengaruh dari Profitabilitas, Llikuiditas (LIQ) danSales Growth terhadap struktur modal (DER) pada perusahaan manufaktur di BEI periode 2014-2018.

Teknik pengambilan sampel yang digunakan adalah proposive sampling dengan jumlah sampel 46 dari 169 perusahaan manufaktur. Teknik analisis yang digunakan adalah analisis regresi linier berganda dan uji hipotesis menggunakan t-statistik untuk menguji koefisien regresi parsial dan F-statistik untuk menguji pengaruh secara bersama-sama atau simultan.

Hasil penelitian secara parsial menunjukkan profitabilitas dan likuiditas berpengaruh negatif signifikan terhadap DER, sedangkan sales growth berpengaruh positif signifikan terhadap DER. Hasil penelitian secara simultan menunjukkan profitabilitas, likuiditas dan sales growth secara bersama-sama berpengaruh terhadap DER.
\end{abstract}

\section{ABSTRACT}

This study aims to analyze whether there is an effect of profitability, liquidity and sales growth on the capital structure of manufacturing companies in the period 2014-2018. The sampling technique used was purposive sampling with a sample of out of 149 manufacturing companies.

The analysis technique used is multiple linear regression analysis and hypothesis testing using $T$ statistics to test the partial stress coefficient and F-statistics to test the effect together or simultaneously.

The results of the research partially show that profitability and liquidity have a significant negative effect on DER while sales growth has a significant positive effect on DER. The results of the study simultaneously show profitability, liquidity and sales growth jointly influence the DER.

Keywords: Profitability, Liquidity, Sales, Growth, BEI 


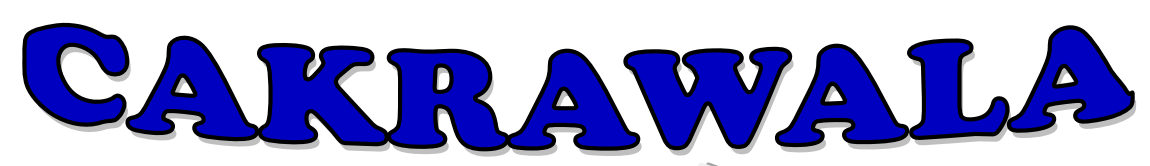

Management Business Journal [C, 2019

\section{PENDAHULUAN}

Kondisi ekonomi di Indonesia yang terus maju pada saat ini, dapat menyebabkan persaingan yang lebih kompetitif antar suatu perusahaan. Dalam menghadapi persaingan yang semakin ketat perusahaan dituntut untuk dapat mempertahankan daya saing serta perusahaan harus dapat melihat dan membaca situasi yang terjadi dalam persaingan. Persaingan dalam suatu perusahaan tidak hanya dihadapi oleh perusahaan jasa, perusahaan dagang dan perusahaan lainnya, tetapi juga perusahaan yang menjalankan bisnis di bagian industri manufaktur. Perusahaan manufaktur merupakan perusahaan yang kegiatan usahanya mengubah barang mentah menjadi barang jadi atau barang setengah jadi. Berdasarkan jenis usahanya, tentu saja perusahaan dalam sektor manufaktur membutuhkan dana yang cukup besar. Oleh karena itu setiap manajer keuangan dituntut harus berhati-hati mengambil keputusan pendanaan atau struktur modal.

Struktur modal merupakan masalah yang sangat penting dalam suatu perusahaan, karena dari struktur modal dapat tercermin financial dari perusahaan tersebut. Struktur modal merupakan perbandingan antara hutang dan equitas atau yang lebih dikenal dengan debt to equity ratio (DER) (Suad Husnan, 2001). Nilai DER akan mempengaruhi penilaian investor. Tinggi rendahnya rasio DER menunjukkan besar kecilnya pendanaan yang berasal dari hutang. Investor cenderung lebih tertarik pada tingkat DER tertentu yang besarnya kurang dari satu, jika besarnya rasio DER lebih dari satu mengidikasikan risiko perusahaan tinggi karena penggunaan hutungnya tinggi. Oleh karena itu perusahaan akan berusaha agar tingkat DER yang dimiliki tidak lebih dari satu dalam struktur pendanaan (Brigham dan Houston, 2001).

Hal penting dalam Manajemen keuangan adalah mengenai seberapa besar kemampuan perusahaan dalam memenuhi kebutuhan dana yang akan digunakan untuk beroperasi dan mengembangkan usahanya. Modal menjadi salah satu elemen penting dalam perusahaan karena dalam bisnis maupun untuk pengembangan bisnis modal sangat diperlukan. Oleh karena itu, perusahaan harus menentukan seberapa banyak modal yang mencerminkan struktur modal optimal untuk keberlangsungan bisnisnya. Perimbangan antara modal asing dan modal sendiri akan mencerminkan struktur modal yang optimal.

Dalam memenuhi kebutuhan dananya perusahaan mengutamakan pemenuhan dengan sumber dari dalam perusahaan dengan mengurangi ketergantungan dari pihak luar. Modal asing hanya digunakan sebagai pelengkap apabila dana yang diperlukan kurang mencukupi. Setiap perluasan yang berbasis modal sendiri akan memperbesar kemampuan perusahaan dalam menanggung risiko usaha yang akan dibelanjainya, hal ini didasarkan pada prinsip keamanan dimana hal ini akan memberikan pengaruh yang baik terhadap kreditur maupun terhadap perusahaan sendiri (Riyanto, 2001). Semakin besar hutang akan menyebabkan semakin besar risiko yang harus dihadapi perusahaan, antara lain kesulitan keuangan, kegagalan membayar bunga dan pokok pinjaman sampai kebangkrutan. Dari kenyataan tersebut, faktor-faktor struktur modal diduga dapat mempengaruhi struktur modal pada perusahaan manufaktur. 


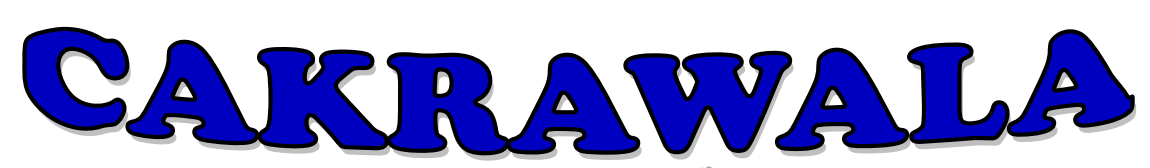

\section{Management Business Journal [CM:B, J] Volume 2 Nomor 2 November Tahun 2019}

Banyak faktor yang dapat mempengaruhi keputusan manajer dalam menentukan struktur modal perusahaan. Menurut Cuong dan Canh (2012) beberapa faktor penentu struktur modal antara lain enterprise size, tangibility of asset, profitabilitas, growth opportunity, resiko bisnis, likuiditas, interest expens, ukuran perusahaan, dan umur perusahaan. Menurut Weston dan Copeland (1999) variabel-variabel yang mempengaruhi struktur modal adalah : tingkat pertumbuhan penjualan, stabilitas arus kas, karakteristik industri, struktur aktiva, sikap manajemen, sikap pemberi pinjaman. Menurut Weston dan Brigham (1998), mengatakan bahwa variabel-variabel yang mempengaruhi struktur modal adalah : stabilitas penjualan, struktur aktiva, leverage operasi, tingkat pertumbuhan, profitabilitas, pajak, pengendalian, sikap manajemen, sikap pemberi pinjaman, kondisi pasar, kondisi internal perusahaan, dan fleksibilitas keuangan.

Penelitian ini bertujuan menganalisis apakah terdapat pengaruh secara parsial dan simultan dar iprofitabilitas, likuiditas dan sales growth terhadap struktur modal (DER) pada perusahaan manufaktur.

\section{METODE PENELITIAN}

Populasi penelitian ini sebanyak 169 perusahaan manufaktur yang tercatat di Bursa Efek Indonesia (BEI). Penentuan sampel dalam penelitian ini dilakukan dengan metode purposive sampling dengan beberapa kriteria pemilihan sampel.Dari populas isebanyak 169 padaperusahaan manufaktur yang memenuhi kriteria sebagai sampel sebanyak 46 perusahaan.

Pada penelitian inistruktur modal (DER) merupakan variabel dependen yang digunakan untuk memproksi hutang (debt) terhadap modal sendiri (equity) pada perusahaan manufaktur yang tercatat di Bursa Efek Indonesia periode 2014-2018. Skala pengukuran DER adalah rasio.

Nilai DER diambil di Indonesian Capital Market Directory (ICMD), dimana ICMD menghitung DER dengan rumus :

$$
\mathrm{DER}=(\text { Total Debt }) /(\text { Total Equity })
$$

Profitabilitas adalah suatu ukuran kemampuan perusahaan dalam menghasilkan laba dalam suatu periode tertentu. Untuk mengukur tingkat profitabilitas dalam penelitian ini, digunakan rasio return on asset (ROA) yang menunjukkan kemampuan perusahaan menghasilkan laba bersih berdasarkan tingkat aset tertentur. Diukur dengan rumus :

\section{Return on asset $=\mathrm{EAT} /($ Total Asset $) \times 100 \%$}

Likuiditas merupakan tingkat kemampuan perusahaan dalam memenuhi kewajiban jangka pendeknya dengan aktiva lancar yang dimilikinya. Current ratio merupakan salah satu rasio likuiditas yang menunjukkan perbandingan antara current asset terhadap current liabilities (Riyanto, 2001). Diukur dengan rumus : 


\section{CAKrawala}

\section{Management Business Journal [[C,M:-B]] Volume 2 Nomor 2 November Tahun 2019}

\section{$\mathrm{CR}=($ Current Asset $) /($ Current Liabilities $)$}

Pertumbuhan penjualan (sales growth) merupakan perubahan atas peningkatan maupun penurunan total penjualan yang dimiliki oleh suatu perusahaan. Pertumuhan penjualan merupakan perbandingan antara perubahan penjualan tahun sekarang dan tahun lalu terhadap penjualan tahun lalu (Brigham dan Houston, 2001). Pertumbuhan penjualan diukur dengan menggunakan rumus :

$$
\text { Growth }=(\text { Salest }- \text { Salest }-1) /(\text { Salest }-1) \times 100 \%
$$

Metode analisis data yang digunakan dalam penelitian ini adalah menggunakan model regresi linier berganda sebagai berikut :

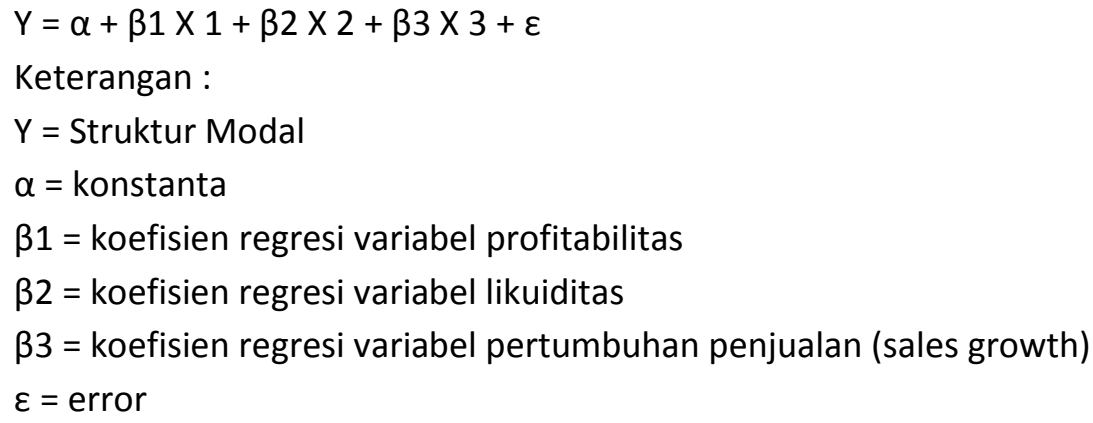

Metode pengujian terhadap hipotesa yang diajukan dilakukan dengan pengujian secara parsial dan pengujian secara simultan. Langkah-langkah untuk menguji hipotesis yang diajukan adalah sebagai berikut :

Uji hipotesisi pada dasarnya menunjukkan seberapa jauh pengaruh satu variabel pendelas/independen secara individual dalam menerangkan variasi variabel dependen. Jika $\mathrm{t}$ signifikan $>5 \%$ atau 0,05 maka artinya, secara parsial tidak ada pengaruh antara variabel independen dengan variabel dependen. Jika t signifikan $<5 \%$ atau 0,05 maka artinya secara parsial ada pengaruh antara variabel independen dengan variabel dependen.

Uji f statistik pada dasarnya menunjukkan apakah semua variabel indepeden atau bebas yang dimasukkan dalam model mempunyai pengaruh secara bersama-sama terhadap variabel dependen/terikat. Jika signifikansi $>0,05$ (5\%) maka hipotesis ditolak (koefisien regresi tidak signifikan). Jika signifikansi > 0,05 (5\%) maka hipotesis diterima (koefisien regresi signifikan).

Koefisien Determinasi dimaksudkan untuk melihat seberapa besar nilai sumbangan yang mampu diberikan oleh variabel independen terhadap variabel dependen, baik secara simultan maupun parsial. Nilai koefisien determinasi adalah antara nol (0) dan satu (1). Jika nilai R2 mendekati 1 , maka dapat dikatakan semakin kuat model tersebut dalam menerapkan variasi 


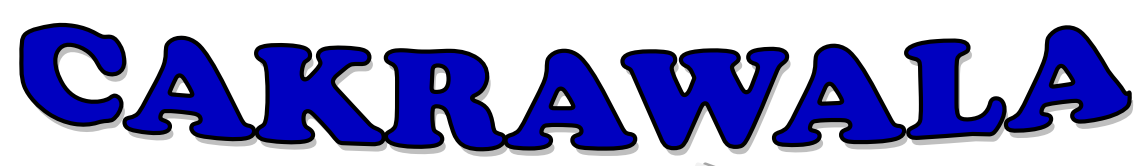

\section{Management Business Journal [CM:B, J] Volume 2 Nomor 2 November Tahun 2019}

variabel independen. Jika nilai R2 mendekati 0 maka semakin variasi pada variabel independen tersebut terhadap variabel dependen.

\section{HASIL PENELITIAN}

Analisis data yang telah diperoleh selama pelaksanaan penelitian. Selanjutnya berdasarkan hasil analisis data tersebut dilakukan pengujian hipotesis penelitian.

Tabel 1

Hasil uji $f$ perusahaan manufaktur

\section{ANOVA $^{a}$}

\begin{tabular}{llrrrrr} 
Model & & Sum of Squares & df & Mean Square & \multicolumn{1}{c}{ F } & \multicolumn{1}{c}{ Sig. } \\
\hline 1 & Regression & 13.330 & 3 & 4.443 & 68.530 & $.000^{b}$ \\
& Residual & 14.653 & 226 & .065 & & \\
& Total & 27.983 & 229 & & & \\
\hline
\end{tabular}

Sumber : Data Sekunder 2019, diolah dengan SPSS 25

Nilai F sebesar 68,530 dengan probabilitas 0,000 , karena probabilitas jauh lebih kecil dari 0,05 atau $5 \%$ maka model regresi dapat digunakan untuk memprediksi DER atau dapat dikatakan bahwa variabel independen yang meliputi ROA, Likuiditas dan Sales Growth secara bersama-sama (simultan) berpengaruh terhadap DER.

Tabel 2

Hasil uji koefisien determinasi perusahaan manufaktur

\begin{tabular}{llrcrr}
\hline \multicolumn{5}{c}{ Model Summary $^{\mathrm{b}}$} \\
\hline Model & $\mathrm{R}$ & $\mathrm{R}$ Square & $\begin{array}{c}\text { Adjusted R } \\
\text { Square }\end{array}$ & $\begin{array}{c}\text { Std. Error of the } \\
\text { Estimate }\end{array}$ & Durbin-Watson \\
1 & $.690^{\mathrm{a}}$ & .476 & .469 & .25463 & 1.922 \\
\hline
\end{tabular}

Sumber : Data Sekunder 2019, diolah dengan SPSS 25

Data yang diperoleh menghasilkan adjusted $R$ square sebesar 0,469 atau $46,90 \%$. Hal ini menunjukan bahwa besar pengaruh variabel ROA, Likuiditas dan Sales Growth terhadap DER yang dapat diterangkan oleh model persamaan ini adalah sebesar $46,90 \%$ dan sisanya sebesar $53,10 \%$ dipengaruhi oleh faktor-faktor lain yang tidak dimasukkan dalam model regresi. 


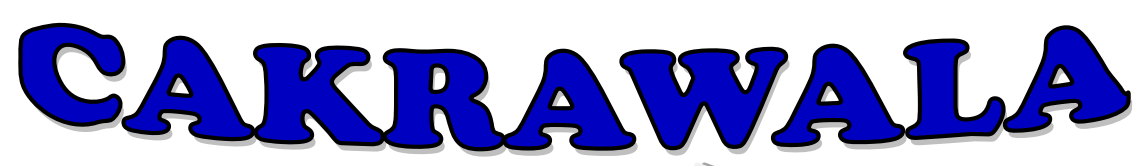

\section{Management Business Journal [CM:B, J] Volume 2 Nomor 2 November Tahun 2019}

Tabel 3

Hasil uji t perusahaan manufaktur

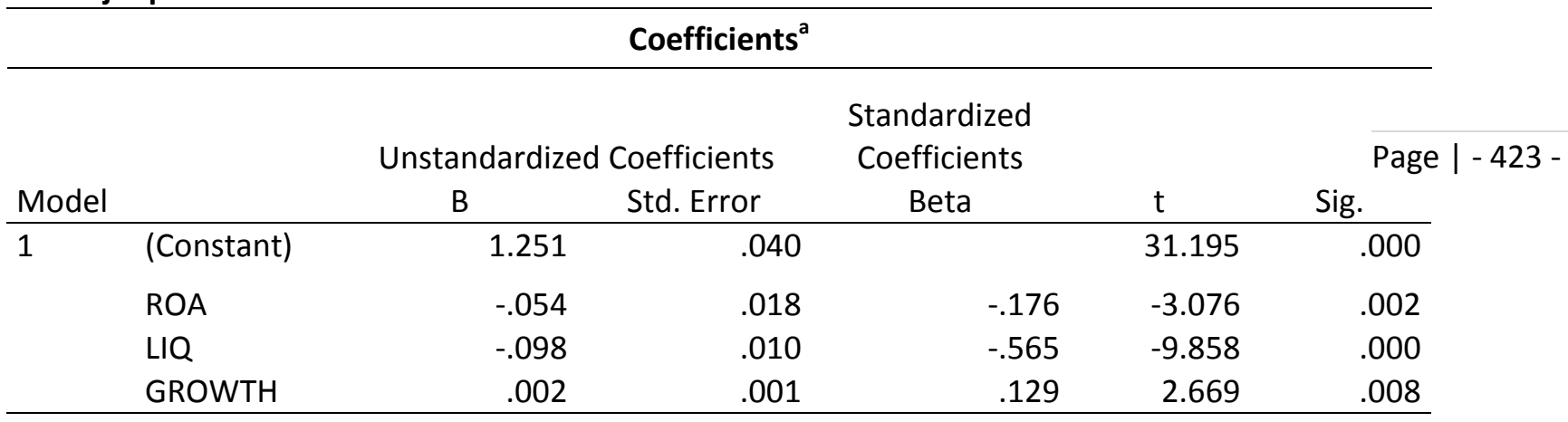

Sumber : Data Sekunder 2019, diolah dengan SPSS 25

Berdasarkan table diatas maka nilai DER sebagai berikut :

$$
\text { DER }=1,251-0,054 \text { ROA - 0,098 LIQ + 0,002 GROWTH }
$$

Persamaan regresi untuk perusahaan manufaktur dapat di interpretasikan sebagai berikut:

Nilai konstanta persamaan di atas adalah sebesar 1,251 yang dapat diartikan bahwa DER akan bernilai 1,251 satuan jika variabel seperti ROA, Likuiditas dan Growth tidak mengalami perubahan atau konstan.

Pada hipotesis ini yang diajukan menyatakan bahwa ROA berpengaruh negatif dan signifikan terhadap DER. Hasil penelitian diperoleh koefisien regresi untuk variabel ROA sebesar -0,054 dengan nilai signifikansi ( $p$-value) sebesar 0,002. Nilai signifikansi ini lebih kecil dari tingkat signifikansi $\alpha$ 0,05 serta t-hitung lebih besar daripada t-tabel $(-3,076>1,654)$ maka hipotesis diterima, berarti terdapat pengaruh negatif dan signifikan antara variabel ROA dengan struktur modal pada perusahaan manufaktur.

Pada hipotesis ini yang diajukan menyatakan bahwa LIQ berpengaruh negatif dan signifikan terhadap DER. Hasil penelitian diperoleh koefisien regresi untuk variabel LIQ sebesar $-0,098$ dengan nilai signifikansi ( $p$-value) sebesar 0,000. Nilai signifikansi ini lebih kecil dari tingkat signifikansi $\alpha$ 0,05 serta t-hitung lebih besar daripada t-tabel $(-9,858>1,654)$ maka hipotesis diterima, berarti terdapat pengaruh negatif dan signifikan antara variabel Likuiditas dengan struktur modal pada perusahaan manufaktur.

Pada hipotesis ini yang diajukan menyatakan bahwa SALES GROWTH berpengaruh positif dan signifikan terhadap DER. Hasil penelitian diperoleh koefisien regresi untuk variabel SALES GROWTH sebesar 0,002 dengan nilai signifikansi (p-value) sebesar 0,008. Nilai signifikansi ini lebih kecil dari tingkat signifikansi $\alpha 0,05$ serta t-hitung lebih besar daripada ttabel $(2,669>1,654)$ maka hipotesis diterima, berarti terdapat pengaruh positif dan signifikan antara variabel SALES GROWTH dengan struktur modal pada perusahaan manufaktur. 


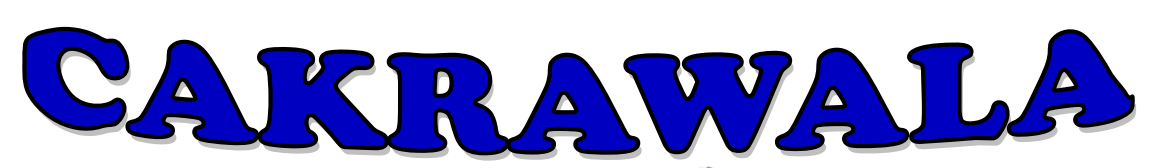

\section{Management Business Journal [CM:B,J] Volume 2 Nomor 2 November Tahun 2019}

\section{PEMBAHASAN}

\section{Pengaruh Profitabilitas Terhadap Struktur Modal (DER)}

Berdasarkan hasil perhitungan uji secara parsial profitabilitas (ROA) diperoleh nilai thitung sebesar -3,076 dengan nilai signifikansi ( $p$-value) sebesar 0,002. Oleh karena nilai signifikansi lebih kecil dari $\alpha$ 0,05, maka berarti profitabilitas berpengaruh negatif dan signifikan terhadap struktur modal. Perusahaan dengan kondisi keuangan yang baik akan meminjam uang lebih sedikit walaupun mempunyai kesempatan untuk meminjam lebih banyak. Pecking order theory mengemukakan bahwa perusahaan cenderung mempergunakan sumber internal sebanyak mungkin sebelum memutuskan untuk berhutang. Semakin tinggi profitabilitas maka semakin rendah rasio hutangnya (Joni \& Lina, 2010).

\section{Pengaruh Likuiditas Terhadap Struktur Modal (DER)}

Berdasarkan hasil perhitungan uji secara parsial Liquidity (LIQ) diperoleh nilai t-hitung sebesar -9,858 dengan nilai signifikansi ( $p$-value) sebesar 0,000. Oleh karena nilai signifikansi lebih kecil dari $\alpha$ 0,05, maka berarti LIQ berpengaruh negatif dan signifikan terhadap struktur modal. Packing order theory menyatakan bahwa perusahaan yang tingkat likuiditasnya tinggi akan lebih memilih untuk tidak menggunakan pendanaan menggunakan hutang, karena perusahaan akan berusaha untuk menggunakan sumber pendanaan internal (Seftianne, 2011). Perusahaan dapat menggunakan aset likuid yang dimiliki sebagai sumber pendanaan atau pembiayaan sehingga membuat perusahaan tidak perlu menggunakan sumber pendanaan yang berasal dari hutang. Semakin tinggi Likuiditas (LIQ) maka semakin rendah rasio utangnya (Retno Yudhiarti, 2011).

\section{Pengaruh Sales Growth Terhadap Struktur Modal (DER)}

Berdasarkan hasil perhitungan uji secara parsial Sales Growth (GROWTH) diperoleh nilai t-hitung sebesar 2,669 dengan nilai signifikansi ( $p$-value) sebesar 0,008. Oleh karena nilai signifikansi lebih kecil dari $\alpha 0,05$, maka berarti sales growth berpengaruh positif dan signifikan terhadap struktur modal. Perusahaan dengan pertumbuhan yang tinggi sebaiknya menggunakan hutang dalam jumlah besar, karena biaya pengembangan pada emisi saham biasa lebih tinggi dibandingkan dengan biaya pada emisi obligasi (Weston dan Copeland, 2000).

\section{KESIMPULAN}

Hasil pengujian pengaruh profitabilitas (ROA) secara parsial menunjukkan bahwa profitabilitas (ROA) memiliki pengaruh negatif dan signifikan terhadap struktur modal (DER). Dengan nilai Thitung sebesar -3,076 dan nilai signifikansi 0,002 dimana lebih kecil dari $\alpha$ 0,05 yang berarti semakin tinggi profitabilitas (ROA) perusahaan maka semakin rendah rasio hutang yang digunakannya.

Hasil pengujian pengaruh likuiditas (LIQ) secara parsial menunjukkan bahwa likuiditas (LIQ) memiliki pengaruh negatif dan signifikan terhadap struktur modal (DER). Dengan nilai 


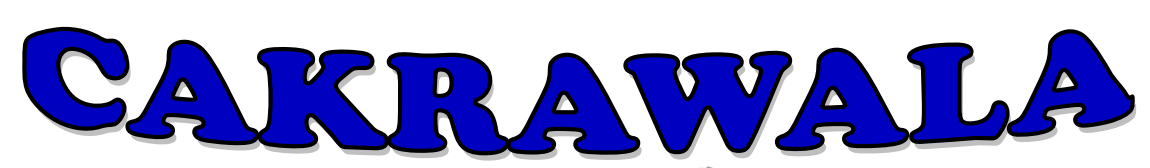

Management Business Journal [CM:-B,] Volume 2 Nomor 2 November Tahun 2019

Thitung sebesar $-9,858$ dan nilai signifikansi 0,000 dimana lebih kecil dari $\alpha$ 0,05 yang berarti semakin tinggi likuiditas (LIQ) perusahaan maka semakin rendah rasio hutang yang digunakannya.

Hasil pengujian pengaruh pertumbuhan penjualan (SALES GROWTH) secara parsial menunjukkan bahwa pertumbuhan penjualan (SALES GROWTH) memiliki pengaruh positifdan signifikan terhadap struktur modal (DER). Dengan nilai Thitung sebesar 2,669 dan nilai signifikansi 0,008 dimana lebih kecil dari $\alpha$ 0,05 yang berarti semakin tinggi pertumbuhan penjualan (SALES GROWTH) perusahaan maka semakin tinggi rasio hutang yang digunakannya.

Hasil pengujian pengaruh profitabilitas (ROA), likuiditas (LIQ), pertumbuhan penjualan (sales growth) secara simultan atau bersama-sama menunjukkan bahwa profitabilitas (ROA), likuiditas (LIQ), pertumbuhan penjualan (sales growth) memiliki pengaruh positif dan signifikan terhadap struktur modal (DER). Dengan nilai Fhitung sebesar 68.530 dan nilai signifikansi 0,000 dimana lebih kecil dari $\alpha 0,05$. Hasil uji adjusted $R 2$ pada penelitian ini sebesar 0,469 . Hal ini menunjukkan bahwa struktur modal perusahaan manufaktur yang terdaftar di Bursa Efek Indonesia periode 2014-2018 dipengaruhi oleh profitabilitas (ROA), likuiditas (LIQ), pertumbuhan penjualan (sales growth) sebesar $46,9 \%$ sedangkan sisanya $53,1 \%$ dipengaruhi oleh variabel lain yang tidak diteliti dalam penelitian ini.

\section{REKOMENDASI}

Beberapa saran yang dapatpenelitisampaikanberdasarkanpenelitian yang disampaikan : Bagi investor disarankan, dalam melakukan pengambilan keputusan investasi perlu memperhatikan profitabilitas, likuiditas, dan sales growth. Hal ini dilakukan agar investasi yang dilakukan memberikan tingkat keuntungan yang maksimal.

Bagi manajer perusahaan harus mampu mempertimbangkan keputusan pendanaan yang akan diambil, baik menggunakan modal sendiri maupun hutang. Pendanaan tersebut pun diharapkan mampu memenuhi kebutuhan perusahaan serta dapat menciptakan struktur modal yang optimum.

Bagi peneliti selanjutnya diharapkan dapat menambah variabel penelitian lainnya yang berpengaruh terhadap struktur modal seperti misalnya variabel independen penelitian dapat ditambahkan seperti : struktur aktiva, ukuran perusahaan, peluang pertumbuhan dan lain sebagainya.

\section{DAFTAR REFERENSI}

Husnan, S, 2001 "Corporate Governance dan Keputusan Pendanaan : Perbandingan Kinerja Perusahaan dengan Pemegang Saham Pengendalian Perusahaan Multinasional dan Bukan Multinasional", Jurnal Riset Akuntansi, Manajemen, Ekonomi, Vol.1 No 1, Februari: 1-12. 


\section{cakrawala}

Brigham, F Eugene and Joel F Houston. 2001. Manajemen Keuangan, Edisi Kedelapan, Jakarta:Erlangga.

Riyanto, Bambang 2001, Dasar-Dasar Pembelanjaan Perusahaan, Yogyakarta: BPFE.

Cuong, Nguyen Thanh dan Nguyen Thi Canh. 2012. The Factors Affecting Capita Structur For Each Debt Rtaio Threshold:Evidence From Vietnam's Seafood International Research Journal Of Finance and Ekonomics.

Weston, J. Fred; Thomas E. Copeland, 1999, Manajemen Keuangan, Terjemahan Wasana, Jaka A. Jilid 1, Jakarta: Binaruoa Aksara.

Weston, J. Fred; Eugene F. Brigham, 1998, Manajemen Keuangan, Terjemahan Wasana, Jaka A. Jilid 2, Jakarta: Binaruoa Aksara.

Weston, JF ; Copeland T.E, 2000, Manajemen Keuangan, Edisi 9, Erlangga Jakarta.

Seftianne \& Ratih Handayani, 2011. Faktor-Faktor Yang Mempengaruhi Struktur Modal Pada Perusahaan Publik Sektor Manufaktur. Jurnal Bisnis dan Akuntansi, Vol. 13, No. 1 : 39-56.

Joni dan Lina. 2010. Faktor-Faktor Yang Mempengaruhi Struktur Modal Perusahaan Manufaktur Periode 2005-2007. Jurnal Bisnis dan Akuntansi Vol.12, No. 2. Agustus 2010. HIm.82-97. 